\title{
Capacity to adapt to environmental change: evidence from a network of organizations concerned with increasing wildfire risk
}

\author{
A. Paige Fischer $^{1}$ and Lorien Jasny ${ }^{2}$
}

\begin{abstract}
Because wildfire size and frequency are expected to increase in many forested areas in the United States, organizations involved in forest and wildfire management could arguably benefit from working together and sharing information to develop strategies for how to adapt to this increasing risk. Social capital theory suggests that actors in cohesive networks are positioned to build trust and mutual understanding of problems and act collectively to address these problems, and that actors engaged with diverse partners are positioned to access new information and resources that are important for innovation and complex problem solving. We investigated the patterns of interaction within a network of organizations involved in forest and wildfire management in Oregon, USA, for evidence of structural conditions that create opportunities for collective action and learning. We used descriptive statistical analysis of social network data gathered through interviews to characterize the structure of the network and exponential random graph modeling to identify key factors in the formation of network ties. We interpreted our findings through the lens of social capital theory to identify implications for the network's capacity to engage in collective action and complex problem-solving about how to adapt to environmental change. We found that tendencies to associate with others with similar management goals, geographic emphases, and attitudes toward wildfire were strong mechanisms shaping network structure, potentially constraining interactions among organizations with diverse information and resources and limiting opportunities for learning and complex problem-solving needed for adaptation. In particular, we found that organizations with fire protection and forest restoration goals comprised distinct networks despite sharing concern about the problem of increasing wildfire risk.
\end{abstract}

Key Words: adaptation; adaptive capacity; collective action; forests; governance networks; organizational networks; social learning; social network analysis; wildfire

\section{INTRODUCTION}

To adapt to environmental change, society must be capable of learning about and collectively adopting new ways of interacting with the environment. Learning from past and present changes in the environment and gaining experience with how to adapt to such changes can enable people to develop and engage in anticipatory actions to prepare for future change (Adger 2003, Berkes et al. 2003, Armitage 2005, Nelson et al. 2007). Collectively sharing information, mobilizing resources, and planning and implementing activities can ensure that such anticipatory actions are coordinated and occur on scales and with impacts sufficient to address environmental change (Adger 2003).

Although both are important for adaptation, the processes of learning and collective action derive from different kinds of social conditions. At the group scale, learning is a social process that entails communication of tacit knowledge within communities of practice, conversion of tacit knowledge to explicit knowledge, combination of different bodies of explicit knowledge, and internalization of new explicit knowledge back into tacit knowledge, again through practice (Nonaka 1994). Social interaction among diverse actors is needed to create opportunities for knowledge sharing that give rise to learning. Taking collective action, on the other hand, requires, among other things, trust and mutual understanding, which develop most readily among people who share similar goals, values, interests, and other attributes (Ostrom 1990, Axelrod 2000, Cohen et al. 2001).

The tendency to associate with similar others runs strong in most social contexts (McPherson et al. 2001). The social cohesion that develops in homogenous groups can foster trust and mutual understanding and thus opportunity for collective action if other conditions are also conducive, e.g., social equality, political culture, and environment (Ostrom 1990). However, homogeneity can also limit opportunity for learning by constraining the diversity of sources of tacit and explicit knowledge (Rogers 1983, Ruef 2002, Berardo and Scholz 2010). Need for new information or resources can counter this tendency (Lin 1999, Berardo and Scholz 2010), as can policy and institutional interventions that bring diverse parties together in frequent and sustained patterns of interaction (Adger 2003, Valente 2012, Angst and Hirschi 2016). Unless other factors constitute insurmountable barriers, shared perception of risk might arguably also compel a diverse set of organizations to coalesce into a cohesive network such that similar organizations interact as frequently as nonsimilar organizations (Berardo and Scholz 2010), especially where policy or institutional interventions have encouraged interaction. Cohesion among a diverse set of organizations would arguably create opportunities for learning and collective action (Jasny and Lubell 2015).

We investigated the structure of a network of organizations in a fire-prone forest landscape that share concern about the problem of increasing wildfire risk for evidence of capacity for learning and collective action. Our goal was to increase understanding of the influences on social network structure that may foster human capacity to adapt to environmental change. This research was part of a larger study on social-ecological adaptation within fire-prone forest landscapes (Spies et al. 2014). By learning about the adaptive capacity of a network of social actors, we aimed to better understand how social systems might influence landscape conditions and vice versa. We also aimed to improve understanding of the role of social network analysis in the study of adaptive capacity in the context of environmental change. Our 
two research questions were as follows: (1) How does the structure of a network of organizations concerned with wildfire risk conform to network structures that promote collective action and learning and thus capacity to adapt to environmental change? (2) What factors explain this structure? Given the natural social tendency to associate with similar others, we hypothesized that in lieu of strong bridging institutions, organizations would interact more frequently with organizations that are similar, e.g., in terms of attitudes toward fire, preferences for management practices, and geographic focus, than organizations that are different, even in cases where all organizations are concerned about a common problem. Such conditions conceivably would foster collective action among sets of similar organizations but would not be conducive to collective action among the broader set of diverse organizations or learning.

\section{Adaptation to increasing wildfire risk}

Despite massive investments in firefighting, wildfires in dry temperate forests around the world are becoming larger and more difficult to control, with great costs to society (Bowman et al. 2011, Flannigan et al. 2013, Moritzet al. 2014). Increasing wildfire risk can be traced to a complex set of interacting factors including abundant flammable vegetation, i.e., hazardous fuels, resulting from past fire exclusion, forest management, and climate change; population growth in forested areas; and the social values, policies, and decisions that guide human behavior (Williams 2013, Spies et al. 2014, Fischer et al. 2016). All the same, fire is an essential ecological process in many temperate forest ecosystems. The fact that fire provides beneficial ecological functions and can cause catastrophic loss of human life and property creates challenging policy and management problems with no simple solutions (Fischer et al. 2016).

Adapting to increasing wildfire risk requires shifts in natural resource management behaviors to reduce the probability of fire and the severity of consequences to the built environment, timber, biodiversity, and other values. Reducing hazardous fuels through thinning to prevent large wildfires and managing large wildfires to reduce their size and intensity are examples of practices land managers can engage in to address the problem of increasing wildfire risk. Given that the probability and potential severity of a wildfire is a function of the composition and distribution of hazardous vegetation sometimes quite distant from the location of a forested stand (Ager et al. 2012), land managers could benefit from coordinating planning and management across property boundaries. Solving the problem of increasing wildfire risk, i.e., reversing the drivers of large wildfires in an enduring way, also requires policies and institutions that foster cooperative planning and management and complex problem solving regarding how to prevent and mitigate the negative effects of increasing wildfire risk.

\section{Networks and adaptive capacity}

The ability to adopt new management and policy strategies in response to environmental change is in part a function of adaptive capacity. Adaptive capacity refers to the ability to actively respond to external stressors by modifying social norms, behaviors, and rules to anticipate or reduce risk (Adger 2003, Nelson et al. 2007). Social structures and processes theorized to engender adaptive capacity include those that affect availability and distribution of resources, capacity to make decisions and act collectively, generation and application of new knowledge, diversity and redundancy in systems, availability of supportive structures for decision making, equity and leadership among local populations, and attachment to or understanding of local ecosystems (Adger 2003, Folke et al. 2003, Pelling and High 2005, Smit and Wandel 2006, Norris et al. 2008, Gupta et al. 2010).

Organizational networks can enhance adaptive capacity by facilitating collective action and learning. Organizational networks are defined as sets of interacting organizations and the ties among them. Ties refer to relationships between organizations, for example interactions for the purpose of working together or sharing information. Organizational networks can serve as collaborative institutional structures uniting stakeholders into both formal and informal arrangements that can help facilitate flows of information and resources. Networks generally form when capabilities of existing organizations are insufficient to complete a given task on their own, and costs prohibit adding to those capabilities internally, and when there are functional gains associated with connecting to others (Benjamin et al. 2011). Because they are not bound to a specific structure, networks can operate across multiple jurisdictions and geographies (multiscalar), have many centers of authority (polycentric), and consist of local to national stakeholders and organizations (multilevel; Powell 2010). This flexible structure allows networks to address large-scale and multijurisdictional problems (Butler and Goldstein 2010).

The structure of an organizational network can provide an indication of the social conditions that foster collective action and learning underlying adaptive capacity (Adger 2003, Pelling and High 2005, Janssen et al. 2006, Lemos and Agrawal 2006, Bodin and Crona 2009). Theories of social capital suggest that dense interactions among actors in the same social group, i.e., bonding social capital structure, promotes communication and cooperation (Borgatti et al. 1998, Berardo and Scholz 2010), transfer of knowledge (Reagans and McEvily 2003), creation of common norms, and development of trust and mutual understanding (Coleman 1990, Burt 2000). Interactions between actors from different groups, i.e., bridging social capital structure, on the other hand, promote access to new information and resources needed for innovation (Granovetter 1973, Rogers 1983, Lin 1999, Burt 2000, Reagans and Zuckerman 2001, Ruef 2002, Reagans and McEvily 2003, Sandström and Carlsson 2008). The structure of social networks falls on a spectrum from highly bonding to highly bridging with no clear thresholds between the two. Social network scholars have advanced concepts and methods for quantifying social capital, often using measures of cohesion and heterogeneity (Borgatti et al. 1998, Burt 2000, Reagans and Zuckerman 2001).

\section{Influences on network structure}

Three primary types of social interaction shape social network structure: homophily, resource seeking, and network interventions. Homophily refers to the socio-psychological tendency for people to associate with others who are similar to them, i.e., share beliefs and values, or who are accessible because they share social strata or physical locations (McPherson et al. 2001). Even among organizations communication of information tends to follow homophilous patterns in organizational attributes, e.g., shared ideology and power-seeking rationales, and geographic locations (Pahor et al. 2008, Škerlavaj et al. 2010a, $2010 b$, Henry 2011, Henry et al. 2011). Homophily can also reflect 
power-seeking rationales, as in the case of organizations with similar goals interacting to leverage each other's resources and form more powerful coalitions. In network analysis, homophily is exhibited when actors that are similar on a given attribute interact more frequently than would be expected by chance (Jasny and Lubell 2015). Resource seeking reflects the tendency to search for additional or rare information and resources (Lin 1999, Borgatti and Cross 2003). Resource seeking is a common driver of the structure of policy networks (Pahor et al. 2008, Škerlavaj et al. 2010a, 2010b). In network analysis, resource seeking is exhibited when actors in one group reach out to others for information or resources more frequently than would be expected by chance. The network measure of indegree centrality, which refers to the number of ties others report having to an actor, can indicate the importance of an actor in a network, specifically the actor's ability to access or relay information and resources and influence decision-making processes. In other words, indegree centrality is a reflection of the potential power of an actor (Wasserman and Faust 1994, Lubell et al. 2014). The network measure anticentrality, also referred to as antipreferential attachment, alternating $k$-stars, or geometrically weighted edgewise shared partners, captures the social tendency for actors with high indegree centrality to gain additional ties preferentially over those with fewer ties, which increases their indegree centrality over time (Lubell et al. 2014). Reciprocity is another notable social tendency that can reinforce homophilous or resource-seeking relationships, especially in bounded networks where actors may expect behaviors to have consequences, e.g., returned generosity (Berardo and Scholz 2010).

Exogenous conditions and events can also shape the structure of social networks. Resource scarcity and chronic stress can motivate competitive behavior, causing people to conceal information from each other rather than share it (Gordon 1954, Gatewood 1984); these conditions can also compel people to cooperate to overcome adversity (Axelrod and Hamilton 1981, Ostrom 1990, Andras et al. 2003, 2007). Scale may mediate the influence of such resource conditions on social structure. People may reduce within-group relationships in response to stress to protect limited information and resources and increase ties outside their group with others to connect with nonredundant resources (Ramirez-Sanchez and Pinkerton 2009). Natural hazard events also influence social structure, in some cases leading to social cohesion within communities (Dynes 1970, Dynes and Quarantelli 1971, Drabeck 1986), and in other cases leading to social conflict (Cuthbertson and Nigg 1987, Carroll et al. 2005, 2011, Tierney 2007, Yoon 2009), especially in economically and socially stratified groups (Cutter 2006) competing for resources (Peacock and Ragsdale 1997). Institutions and policies can impose social structure on people, shaping the kinds of social processes people engage in, for example, by bringing people who otherwise would not associate with each other together in patterns of interaction that promote social cohesion or learning (Mandarano 2009, MuñozErickson et al. 2010). Nevertheless, structural forces such as power dynamics may hinder such efforts (Macy et al. 2003).

\section{RESEARCH DESIGN}

We used social network analysis of relational data gathered through qualitative interviews to explain patterns of interaction among organizations concerned with increasing wildfire risk and identify implications for adaptive capacity. Social network analysis has been used in sociology and organizational studies to quantify structural conditions for communication, cooperation, and joint problem solving (Borgatti et al. 1998, Lin 1999, Burt 2000), including in natural resource management contexts (Bodin et al. 2006, Bodin and Crona 2009, Berardo and Scholz 2010, Lubell et al. 2010, Newig et al. 2010). Some scholars have used social network analysis to investigate capacity to adapt to environmental change (e.g., Bodin and Norberg 2005, Sandström and Rova 2010b, Cassidy and Barnes 2012), although use of inferential models to explain network structure has been limited (for notable exceptions, see Desmarais and Cranmer 2012, Lubell et al. 2014).

\section{Study area}

Our study area was largely defined by the Eastern Cascade Slopes and Foothills Ecoregion (Omernik 1987) in Oregon (ECE), a landscape of 3.3 million hectares that crosses 5 counties and includes several small cities and large expanses of ponderosa pine (Pinus ponderosa) and mixed-conifer forest inhabited by wildlife species of federal and state policy interest, e.g., Northern Spotted Owl (Strix occidentalis caurina) and mule deer (Odocoileus hemionus), a popular game species (Fig. 1). Two-thirds of the land area is in public ownership, mostly federal; one-sixth is held by tribes and corporate forestry entities; and the remaining one-sixth is owned by noncorporate private landowners, e.g., individuals, families, and trusts. Our social network analysis included all but the northernmost portion of the ecoregion, the eastern flanks of Mount Hood, which is tied to the expansive networks of organizations in the large urban area of Portland, Oregon.

Fig. 1. Study area.

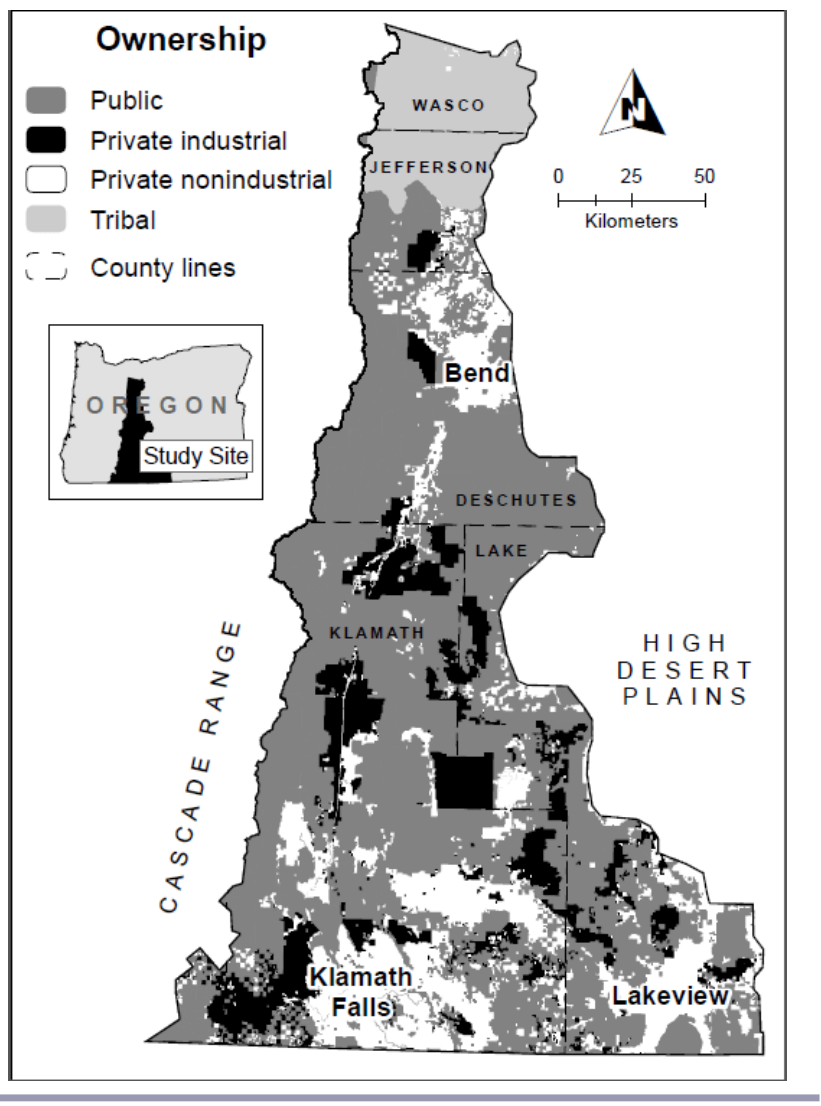


Fire was a frequent ( $<35$ years) and ecologically important process in many of the forest types of the ECE. However, the past century of fire suppression, commercial logging, and livestock grazing, combined with drought and incursions by invasive plants, insects, and diseases, has led to an accumulation of flammable forest vegetation (Hessburg et al. 2005, U.S. Forest Service 2009), now fueling fires that are less frequent but larger in size, i.e., "megafires" (Williams 2013), and may burn with higher severity effects than when they burned frequently, e.g., many ponderosa pine and mixed-conifer forests in the area burned every 10 to 25 years (Agee 1993). This alteration of the historical fire regime is changing the assemblages of natural communities in the ECE (Hessburg et al. 2005, Merschel et al. 2014).

Efforts to address the problem of increasing wildfire risk have coalesced around two primary strategies in fire-prone landscapes such as the ECE: restoring forests by thinning vegetation to create conditions under which wildfire can burn more frequently and with less intensity and protecting assets that humans value from damage by wildfire by thinning vegetation to prevent fire from reaching those assets. Some forest restoration and fire protection activities can be mutually beneficial. For example, thinning followed by prescribed fire to restore desired structure can reduce flammable vegetation (Charnley et al. 2017). Although some ecosystem restoration treatments reduce hazardous fuel, not all fuel treatments restore ecosystems (Reinhardt et al. 2008). The U. S. Forest Service (FS) historically favored fire protection, but national forest managers now pursue forest restoration strategies and, in some cases, allow wildfire to burn where it is not a threat to life and property. However, the FS also still spends more on fire suppression than any other activity, and some state and federal agencies continue to consider wildfire a public nuisance (Oregon State Legislature 2013). Private property owners generally have a low tolerance for fire, avoiding prescribed fire and aggressively suppressing wildfire to reduce risk damage to homes, timber, and fence lines on their properties (Fischer 2011, Charnley et al. 2017).

A number of organizational partnerships have formed in the ECE in recent years to address the problem of increasing wildfire risk. For example, The Nature Conservancy (TNC) administers two Fire Learning Networks (FLN), also supported by the FS, which engage land management organizations in the restoration, i.e., intentional activities that initiate or accelerate the recovery of an ecosystem with respect to its health, integrity, and sustainability (SER International Science and Policy Working Group 2004), of fire-dependent ecosystems through landscape-scale collaborative planning, regional capacity building, and national coordination (Butler and Goldstein 2010). The FS and the Bureau of Land Management (BLM) have formed formal partnerships around wildfire response. Less formal network institutions have also emerged such as prescribed fire councils, which engage local landowners, land managers, and other stakeholders in efforts to increase social and political support for prescribed fire and the capacity to implement it across jurisdictional lines. Recent policy innovations have also encouraged partnerships and information sharing. The Collaborative Forest Landscape Restoration Program has funded projects on the Fremont-Winema and the Deschutes National Forests that engage local public land managers and stakeholder groups in management planning. All lands management, a directive in the 2012 FS planning rule, encourages coordination of planning and management actions across larger spatial scales than typical in forest management. Similarly, the intent of the National Cohesive Wildland Fire Management Strategy of 2009, mandated as part of the Federal Land Assistance, Management and Enhancement (FLAME) Act, is to balance local, state, and federal fire protection goals with the need to restore fire-adapted landscapes and create human communities that can plan for, respond to, and recover from wildfires. These policies and formal and informal network institutions arguably should help build relationships among diverse organizations concerned with increasing wildfire risk in the ECE.

\section{Data collection}

The research team conducted semistructured interviews with representatives of organizations involved with the management of wildfire and fire-prone forests in the ECE to collect the network data for our study, which included information about relationships and interactions (ties) among organizations through which information and resources are shared and attributes of organizations. We first asked informants open-ended interview questions about their organizations' (1) goals for fire-prone forest and wildfire risk management, including the types of land ownership they sought to influence; (2) preferred practices for wildfire and fire-prone forest management, including the scale on which planning and management should occur; and (3) attitudes toward wildfire. We then asked interview informants to name individuals in other organizations with whom they had interacted in the past five years to (1) plan, fund, or implement fire-prone forest or wildfire risk management work; (2) obtain information or expertise about fire-prone forest or wildfire risk management; (3) give formal advice about fire-prone forest or wildfire risk management, i.e., as a member of a board or committee; (4) unexpectedly gain exposure to new ideas, e.g., as a result of unplanned encounters; and (5) influence planning and management relating to fire-prone forest or wildfire risk management.

We used a snowball sampling approach to identify the individuals we would interview and thus the central organizations in the network (Laumann et al. 1983, Doreian and Woodard 1992). Our snowball sample seed consisted of 45 individuals who we knew were key actors in the domain of wildfire risk and fire-prone forest management. We conducted second and third waves of snowball sampling by contacting the additional individuals who were named in response to the five network questions by at least three interviewees in the preceding wave. The third wave of snowball sampling did not identify any additional interview informants, therefore reaching saturation. In total, the research team interviewed 154 individuals representing 87 organizations.

The unit of analysis we used was the organization. In most cases, we considered local government agencies, private businesses, and nonprofit groups as single organizations. For complex organizations such as universities, state and federal agencies, and nonprofit groups operating at state and national levels, we treated local and regional offices and departments as unique organizations. For example, we considered FS national forest supervisor offices and ranger district offices as separate organizations. To prepare the data for quantitative analysis, we drew on the informants' answers to the open-ended interview 
questions to classify the organizations by the following attributes: (1) whether they focused on the ecoregion as a whole or the northern or southern portions of the ecoregion; (2) whether they were primarily concerned with forest restoration or fire protection goals; (3) whether they sought to influence forest and fire risk conditions on federal or nonfederal lands; (4) whether they planned or managed across ownership boundaries or just on single ownership types; and (5) their attitude toward wildfire, on a scale from 1, being very negative, e.g., fires should never be allowed to burn in forested areas even when assets are not at risk, to 5 , being very positive, e.g., fires should always be allowed to burn in forested areas of the ECE even when assets are at risk. In cases where we interviewed more than one individual from an organization, we averaged their responses to the non-network questions to create one set of attributes per organization, and we collapsed their responses to the network questions into one nonredundant set of ties. This allowed us to maintain organizations as the unit of analysis and avoid overrepresentation of organizations for which we interviewed more than one representative. This process yielded a multirelational data set of ties among 87 central organizations concerned with increasing wildfire risk in the ECE and attributes of these organizations.

\section{Data analysis}

We used social network analysis to quantify and explain the composition and distribution of ties among organizations. We limited our analysis to the 87 organizations from which we collected attribute data through interviews. We also limited our analysis to the sets of organizations that reported interacting for the purpose of (1) planning, funding, or implementing work, hereafter referred to as the "works with" network, and (2) obtaining information or expertise, hereafter referred to as the "info from" network, because cooperation and resource seeking are two primary types of interactions among organizations. Both networks are "directed," meaning that we differentiate between the sender, i.e., the organization represented by an interviewee, and the receiver, i.e., the organization represented by the person named by the interviewee. A directed tie is called an edge in the network literature. For the "works with" network, an edge indicates that the sender reported working with the receiver organization. Similarly, for the "info from" network, an edge indicates that the respondent obtained information from the recipient of the tie. We calculated density, i.e., the proportion of possible edges that were reported, to measure the cohesiveness of the networks, and we calculated indegree centrality, i.e., the average number of times organizations were named in response to the network questions, to measure the potential power or influence of the organizations.

Exponential random graph (ERG) modeling served as our method for explaining the likelihood of an edge between any two organizations for the purpose of working together and seeking information and expertise, and thus the structure of each network. ERG models are statistical models permitting inferences about how network ties are patterned to understand how and why social ties arise (Lusher et al. 2013). ERG models are similar to logistic regression models in that they predict the binary outcome variable of a tie. Network variables, i.e., terms, function similarly to their logistic counterparts; the coefficients indicate the change in the $\log$ odds of a given tie if it increases the count of such network configurations by 1 . What makes ERG models different from logistic regression models and more suitable for explaining network structure is that they can take into account social influences that make network structure nonindependent. ERG models simulate thousands of alternate networks that have, on average, the empirical values of the statistics for the observed network. By conditioning on the expected number of different types of tie configurations, e.g., reciprocated ties, certain terms in ERG models make the likelihood of a given tie dependent on other ties in the network.

The network variables that we included in the ERG models were the variables that capture well-recognized influences on network structure according to the literature: homophily, and its inverse, heterophily; indegree centrality; anticentrality; and reciprocity (Table 1). These network variables have been used in other applications of ERG models in investigations of natural resource governance networks (e.g., Lubell et al. 2014). We used the ERG models to test for the presence of any of these network influences on the patterns of interaction among organizations in our network based on their attributes. We calculated social network measures and produced their graphic representations using UCINET (Borgatti et al. 2002) and ran ERG models in the statnet package of R (Goodreau et al. 2008, R Development Core Team 2013).

\section{RESULTS}

We identified 701 edges among the 87 organizations in the "works with" network and 231 edges among the 87 organizations in the "info from" network (Fig. 2a, b). Organizations were named as working partners by 8 other organizations on average and as information sources by 3 other organizations on average (average indegree centrality). Interviewees reported about $9 \%$ of all possible working relationships among organizations and about $4 \%$ of all possible information-seeking relationships (density). Both the "works with" and "info from" networks were sparser than would be expected by chance in networks of the same size, as demonstrated by the negative and significant edges term in the results of the ERG model, which can be thought of as an intercept term, the base probability of observing a tie if all other terms are held constant. Table 2 presents these results in log-odds form, which we convert using the inverse logit to a probability. Low density is typical in most social networks because the number of social relationships that people and organizations can maintain is limited, as is the number of relationships informants are capable of reporting in an interview. The organizations in the "works with" network, however, were more densely interconnected than the "info from" network. The chance of an organization reporting a working relationship with another organization was $3.2 \%$ if all other significant terms in the model remained unchanged, whereas the chance of an organization seeking information from another organization was $0.7 \%$.

The tendency toward reciprocity shaped the structure of the "works with" network, as evident in the positive and significant reciprocity term (Table 2). Holding all other terms constant, when an organization named another organization as a working partner there was an $18.5 \%$ chance of that tie being reciprocated, calculated as the inverse logit of the sum of the log odds of reciprocity, 1.91, and the log odds of an edge overall, -3.39 (see Goodreau et al. 2008). The probability of a reciprocated edge was approximately 6 times larger than that of an unreciprocated edge. Reciprocity was not a significant influence on the structure of the "info from" network, as expected in social interactions that involve resource seeking (Table 2). 
Table 1. Variables used in exponential random graph model.

\begin{tabular}{|c|c|c|c|}
\hline Variable Name & $\begin{array}{l}\text { Graphic } \\
\text { Representation }\end{array}$ & Definition & Attributes Included \\
\hline Edges (intercept) & & $\begin{array}{l}\text { Parameter that ensures the estimated model } \\
\text { produces networks with a density equal to the } \\
\text { observed density }\end{array}$ & None \\
\hline Reciprocity & & Tendency for sent edges to be returned & None \\
\hline Anticentrality & & $\begin{array}{l}\text { Tendency to not receive additional ties if it is } \\
\text { already named by others, i.e., when negative, } \\
\text { indicates increasing popularity (Barabási and } \\
\text { Albert 1999, Snijders et al. 2006) }\end{array}$ & None \\
\hline $\begin{array}{l}\text { Indegree centrality } \\
\text { (categorical attribute } \\
\text { variables) }\end{array}$ & & $\begin{array}{l}\text { Tendency to be named as a recipient if the node } \\
\text { is of a specific class of a given attribute }\end{array}$ & $\begin{array}{l}\text { Ecoregion (-north, -south, and } \\
\text {-wide) } \\
\text { Forest restoration versus fire } \\
\text { protection } \\
\text { Federal versus nonfederal } \\
\text { lands } \\
\text { Cross-boundary versus within } \\
\text { ownership planning }\end{array}$ \\
\hline $\begin{array}{l}\text { Indegree centrality } \\
\text { (continuous attribute } \\
\text { variables) }\end{array}$ & & $\begin{array}{l}\text { Tendency to be named in response to the } \\
\text { network questions when the organization scores } \\
\text { higher along a continuous scale for a given } \\
\text { attribute }\end{array}$ & Fire attitude \\
\hline $\begin{array}{l}\text { Homophily (categorical } \\
\text { attribute variables) }\end{array}$ & & $\begin{array}{l}\text { Tendency to be named in response to the } \\
\text { network questions when both the sender and } \\
\text { receiver share the same class of a given } \\
\text { attribute }\end{array}$ & $\begin{array}{l}\text { Ecoregion (-north, -south, and } \\
\text {-wide) } \\
\text { Goals (forest restoration vs. } \\
\text { fire protection) } \\
\text { Target lands (federal vs. } \\
\text { nonfederal) } \\
\text { Target lands (federal vs. } \\
\text { nonfederal) }\end{array}$ \\
\hline $\begin{array}{l}\text { Heterophily (continuous } \\
\text { attribute variables) }\end{array}$ & & $\begin{array}{l}\text { Tendency to be named in response to the } \\
\text { network questions when the difference in } \\
\text { naming and named organizations' scores on a } \\
\text { given attribute decreases }\end{array}$ & Fire attitude \\
\hline
\end{tabular}

Table 2. Results of the exponential random graph model of the likelihood of an organization naming another organization.

\begin{tabular}{|c|c|c|}
\hline Explanatory Variables & Works With & Info From \\
\hline Edges & $-3.39(0.24) * * *$ & $-4.91(-.42)^{* * *}$ \\
\hline Reciprocity & $1.91(0.14)^{* * *}$ & $.37(0.35)$ \\
\hline Anticentrality & $-3.08(0.27)^{* * *}$ & $-2.89(0.23)^{* * *}$ \\
\hline Indegree centrality: ecoregion-wide & $0.94(0.20)^{* * *}$ & $1.12(0.30) * * *$ \\
\hline Indegree centrality: ecoregion-south & $-0.06(0.22)$ & $0.41(0.32)$ \\
\hline Indegree centrality: forest restoration & $0.04(0.19)$ & $0.53(0.29)$ \\
\hline Indegree centrality: federal lands & $0.13(0.17)$ & $0.64(0.23)^{* *}$ \\
\hline Indegree centrality: cross-boundary planning & $0.03(0.15)$ & $-0.13(0.18)$ \\
\hline Indegree centrality: fire attitude & $-0.21(0.05)^{* * *}$ & $-0.12(0.06)^{*}$ \\
\hline Homophily: ecoregion-north & $1.89(0.16)^{* * *}$ & $2.21(0.27)^{* * *}$ \\
\hline Homophily: ecoregion-wide & $1.07(0.35)^{* *}$ & $1.52(0.48)^{* *}$ \\
\hline Homophily: ecoregion-south & $1.89(0.18)^{* * *}$ & $1.67(0.27)^{* * *}$ \\
\hline Homophily: goal, fire protection & $0.05(0.15)$ & $0.99(0.31)^{* *}$ \\
\hline Homophily: goal, forest restoration & $0.71(0.13)^{* * *}$ & $0.99(0.21)^{* * *}$ \\
\hline Homophily: target lands, federal & $0.27(0.14)^{*}$ & $0.02(0.21)$ \\
\hline Homophily: target lands, nonfederal & $0.27(0.13)^{*}$ & $0.93(0.26) * * *$ \\
\hline Homophily: planning scale, across & $0.05(0.17)$ & $-0.00(0.31)$ \\
\hline Homophily: planning scale, within & $0.13(0.11)$ & $-0.05(0.18)$ \\
\hline Heterophily: fire attitude & $-0.10(0.04)^{*}$ & $-0.14(0.08)$ \\
\hline Bayesian information criterion & 3611 & 1841 \\
\hline
\end{tabular}


Fig. 2. Graphic representations of the 87 organizations concerned with increasing wildfire risk in the study area and the ties the organization representatives reported with the organizations that (a) they work with and (b) from which they seek information and expertise.

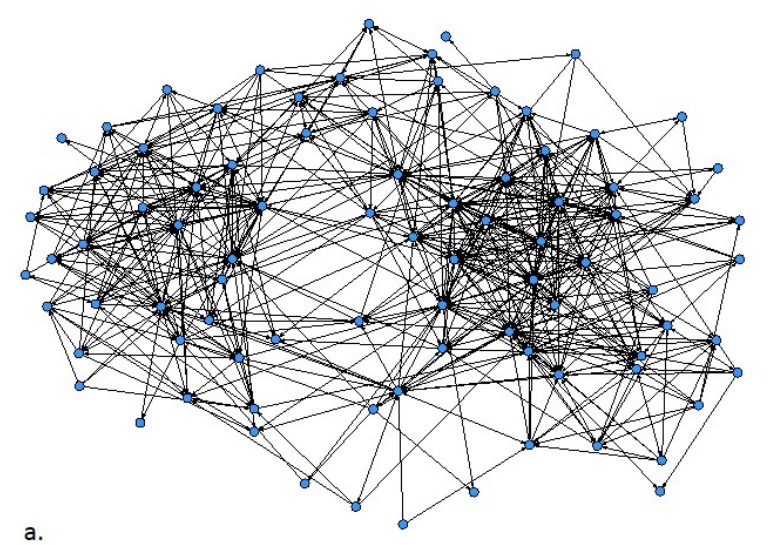

a.

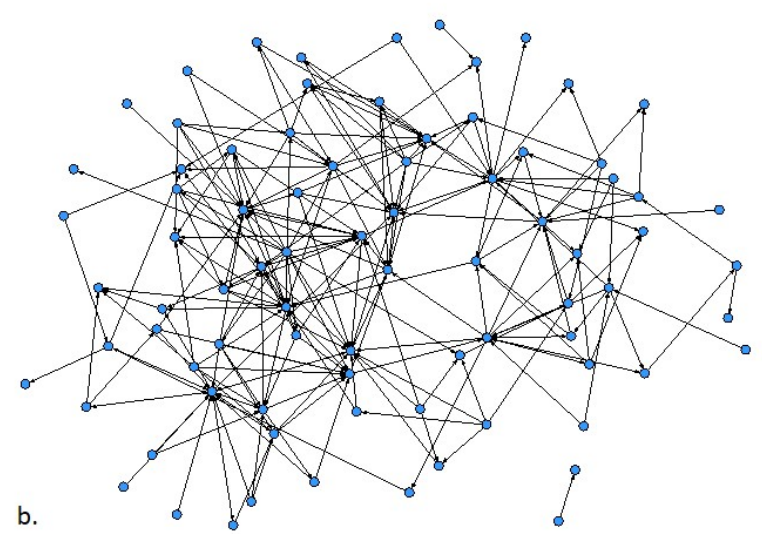

Anticentrality also shaped the structure of both the "works with" and "info from" networks. Anticentrality, when negative, refers to the tendency for organizations with many ties to become more central, i.e., accumulate more ties, over time. The anticentrality term was negative and significant in both networks indicating that many organizations tended to work with and seek information from the same organizations (Table 2). Organizations with high indegree centrality, i.e., those named by many other organizations, are likely to be chosen again and again by other organizations in the network as both working partners and information sources.

Some types of organizations tended to be more central, i.e., have higher indegree centrality, as working partners and information sources than other organizations, as indicated by positive and significant indegree centrality terms for organizations with an ecosystem-wide geographic focus, forest restoration goals, and more negative fire attitudes (Table 2). Despite their small number $(n=10)$, ecoregion-wide organizations were more likely to be considered working partners and information sources than ecoregion-north and ecoregion-south organizations. Organizations that held more negative attitudes toward the role of fire in fireprone forests were more likely to be considered working partners and information sources than organizations with more positive attitudes. Organizations with forest restoration goals were no more likely to be considered working partners and information sources than organizations with fire protection goals. Organizations that sought to influence conditions on federal lands were no more likely to be named as working partners than organizations that sought to influence conditions on nonfederal lands, although they were more likely to be named as information sources. The likelihood of organizations naming ecoregion-north and ecoregion-south organizations as working partners or information sources was not significantly different. Also, organizations that planned and managed across ownership boundaries were no more likely to be named than organizations that focused on single ownership types.

Above and beyond these general social tendencies, organizations tended to work with organizations with the same geographic focus, goal, target lands, and fire attitude, as is evident in the positive and significant homophily terms and the negative and significant heterophily terms (Table 2). Similarly, organizations tended to seek information from organizations with the same geographic focus, goal, and target lands. Specifically, forest restoration organizations were more likely to work with and source information from other forest restoration organizations than fire protection organizations (Table 2). Fire protection organizations were more likely to source information from other fire protection organizations than forest restoration organizations, although they were not more likely to work together. Organizations that manage or seek to influence conditions and practices, i.e., target, on federal lands were more likely to work with one another than organizations that focused on nonfederal lands, and organizations focused on nonfederal lands were more likely to both work with and seek information from other organizations focused on nonfederal lands than organizations focused on federal lands (Table 2). Organizations were not more likely to work with or seek information from organizations that were similar in whether they planned or managed across different types of ownerships or just for single types of ownerships, and organizations were not more likely to seek information from organizations with similar attitudes toward fire as compared with organizations with dissimilar attitudes toward fire (Table 2); however, they were more likely to seek out like-minded organizations as working partners. These findings highlight subtle differences between the two network processes and show that different organizational attributes are more important for cooperation or information gathering. Overall, the numbers of significant terms for homophilous sorting indicate strong preferences for associating with organizations that are similar across many attributes.

Although homophily clearly structured the network overall, and one-third of the organizations did not have any ties with organizations that differed on any of the five attributes studied, some organizations exhibited more heterophilous tendencies than others. For example, FS Deschutes National Forest (FS Deschutes NF), Oregon Wild, and TNC Central Oregon had more heterophilous working ties than other organizations (Table 3, Fig. 3), and Oregon State University College of Forestry Department of Forest Ecosystems and Society (OSU CoF FES), Oregon State University College of Forestry Extension (OSU CoF Extension), FS Deschutes NF, and FS Deschutes National 
Table 3. Top 10 organizations ranked by total number of heterophilous ties to working partners.

\begin{tabular}{|c|c|c|c|c|c|c|c|}
\hline & \multirow[b]{2}{*}{$\begin{array}{l}\text { Indegree } \\
\text { Centrality }\end{array}$} & \multicolumn{6}{|c|}{ Heterophilous Ties } \\
\hline & & Geography & Goals & $\begin{array}{l}\text { Target } \\
\text { Lands }\end{array}$ & $\begin{array}{c}\text { Planning } \\
\text { Scale }\end{array}$ & $\begin{array}{c}\text { Fire } \\
\text { Attitude }\end{array}$ & Total \\
\hline FS Deschutes NF & 27 & 5 & 12 & 15 & 5 & 17 & 54 \\
\hline Oregon Wild & 25 & 8 & 5 & 8 & 14 & 15 & 50 \\
\hline TNC Central Oregon & 25 & 4 & 9 & 9 & 9 & 18 & 49 \\
\hline Interfor & 17 & 4 & 12 & 8 & 6 & 16 & 46 \\
\hline OSU CoF Extension & 19 & 6 & 10 & 7 & 8 & 13 & 44 \\
\hline FS Deschutes NF Sisters RD & 19 & 1 & 6 & 10 & 15 & 11 & 43 \\
\hline Collins Pine Co. & 16 & 1 & 10 & 10 & 5 & 16 & 42 \\
\hline ODF Fire Central Oregon District & 23 & 3 & 9 & 7 & 5 & 18 & 42 \\
\hline TNC Klamath Basin & 19 & 3 & 7 & 10 & 6 & 15 & 41 \\
\hline FS Fremont-Winema NF & 20 & 6 & 10 & 10 & 4 & 8 & 38 \\
\hline
\end{tabular}

FS Deschutes NF, U.S. Forest Service Deschutes National Forest; FS Deschutes NF Sisters RD, U.S. Forest Service Deschutes National Forest Sisters Ranger District; FS Fremont-Winema NF, U.S. Forest Service Fremont-Winema National Forest; ODF Fire, Oregon Department of Forestry's Fire Protection Division; OSU CoF Extension, Oregon State University College of Forestry Extension; TNC, The Nature Conservancy.

Forest Sisters Ranger District (FS Deschutes NF Sisters RD) had more heterophilous information-seeking ties than other organizations (Table 4, Fig. 4). Some organizations exhibited heterophilous tendencies on some attributes and not others. For example, three of the organizations with the most heterophilous ties based on geography, i.e., Cascade Timberlands, Sustainable Northwest, and the Walker Range Forest Protection Association (Table 5), did not have particularly heterogeneous networks when ties across all attributes were combined (Tables 3 and 4).

\section{DISCUSSION}

\section{Implications for adaptive capacity}

The capacity to adapt to environmental change is a function of people's ability to generate new knowledge and collectively make and act on decisions based on this knowledge (Adger 2003, Folke et al. 2003, Pelling and High 2005, Smit and Wandel 2006, Nelson et al. 2007, Norris et al. 2008, Gupta et al. 2010). We identified a substantial number of organizations that were concerned about increasing wildfire risk in the ECE. Despite sharing this concern, organizations that worked on fire-prone forest and wildfire management issues in the ECE did not comprise one cohesive network. Organizations were more likely to work with and seek information and expertise from organizations that were similar to them rather than organizations that were different. When interpreted with social capital theory, these findings provide limited evidence of structural conditions that promote adaptive capacity. They do not suggest a pattern of frequent interaction that can build bonding social capital in the overall network, which fosters communication and collective action (Borgatti et al. 1998, Burt 2000, Reagans and McEvily 2003), nor do they reveal a network of organizations engaged in diverse relationships that build bridging social capital, which can foster cross-pollination of ideas needed for innovation and complex problem solving (Granovetter 1973, Rogers 1983, Coleman 1990, Lin 1999, Burt 2000, Reagans and Zuckerman 2001, Ruef 2002, Reagans and McEvily 2003, Sandström and Carlsson 2008, Sandström and Rova 2010a). Other studies with similar findings about social network structure have concluded that excessive bonding social capital relative to bridging social capital has impeded adaptive behavior (Gargiulo and Benassi 2000, Wolf et al. 2010).

Geography was one of the most powerful influences on tie formation. Despite facing a similar threat in an area with similar ecological conditions, we found that organizations in the northern and southern portions of the ecoregion were not strongly connected via the social processes of working together and sharing information. This finding of geographic homophily is not surprising. People are more likely to have contact with those who are closer geographically than those who are distant because they are more accessible (McPherson et al. 2001). As organizations are composed of people, propinquity drives interorganizational relationships as well. The spatial scale of our study area likely amplifies the influence of geographic homophily; ecoregions, because of their size, encompass multiple ecological and social territories, whereas people tend to develop connections to place at local scales (Fall 2003, Powell 2010). In a related study, receiving information from a local organization was positively associated with wildfire risk perception among homeowners, which was itself positively associated with risk mitigation behavior, whereas receiving information from nonlocal organizations was not (Olsen et al. 2017).

The finding of geographic homophily may also reflect the logic of communicating about and jointly implementing natural resource management at smaller spatial scales than the landscape or ecoregion. Although accumulation of flammable forest vegetation is an ecoregion-wide problem, coordinated thinning and prescribed burning may make more sense on smaller scales. For example, although a number of collaborative approaches to fire-prone landscapes have emerged in recent years in the ECE, e.g., TNC's FLN, their geographic focus for planning and management has been much narrower than the ecoregion. Because wildfire events rarely if ever burn across areas the size of the ECE, the lack of cross-ecoregion interactions among fire protection organizations, which respond to wildfire outbreaks, is particularly understandable. 
Fig. 3. Graphic representation of organizations and their ties to organizations with which they report working. Nodes sized by popularity, i.e., larger indicates greater indegree centrality, and shaded by diversity of ties, i.e., darker indicates more heterophilous ego networks.

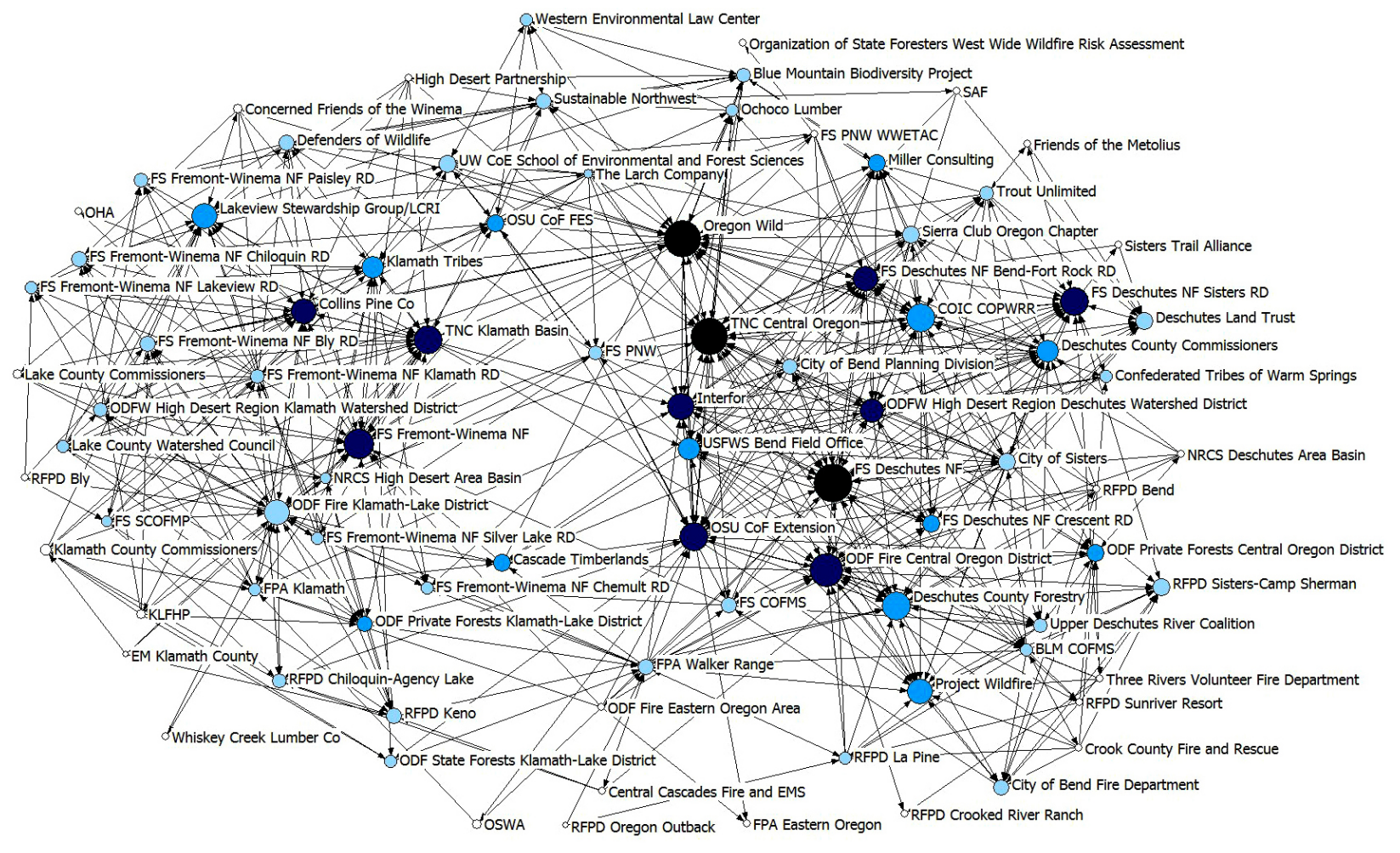

Fig. 4. Graphic representation of organizations and their ties to organizations from which they report seeking information and advice. Nodes sized by popularity, i.e., larger indicates greater indegree centrality, and shaded by diversity of ties, i.e., darker indicates more heterophilous ego networks.

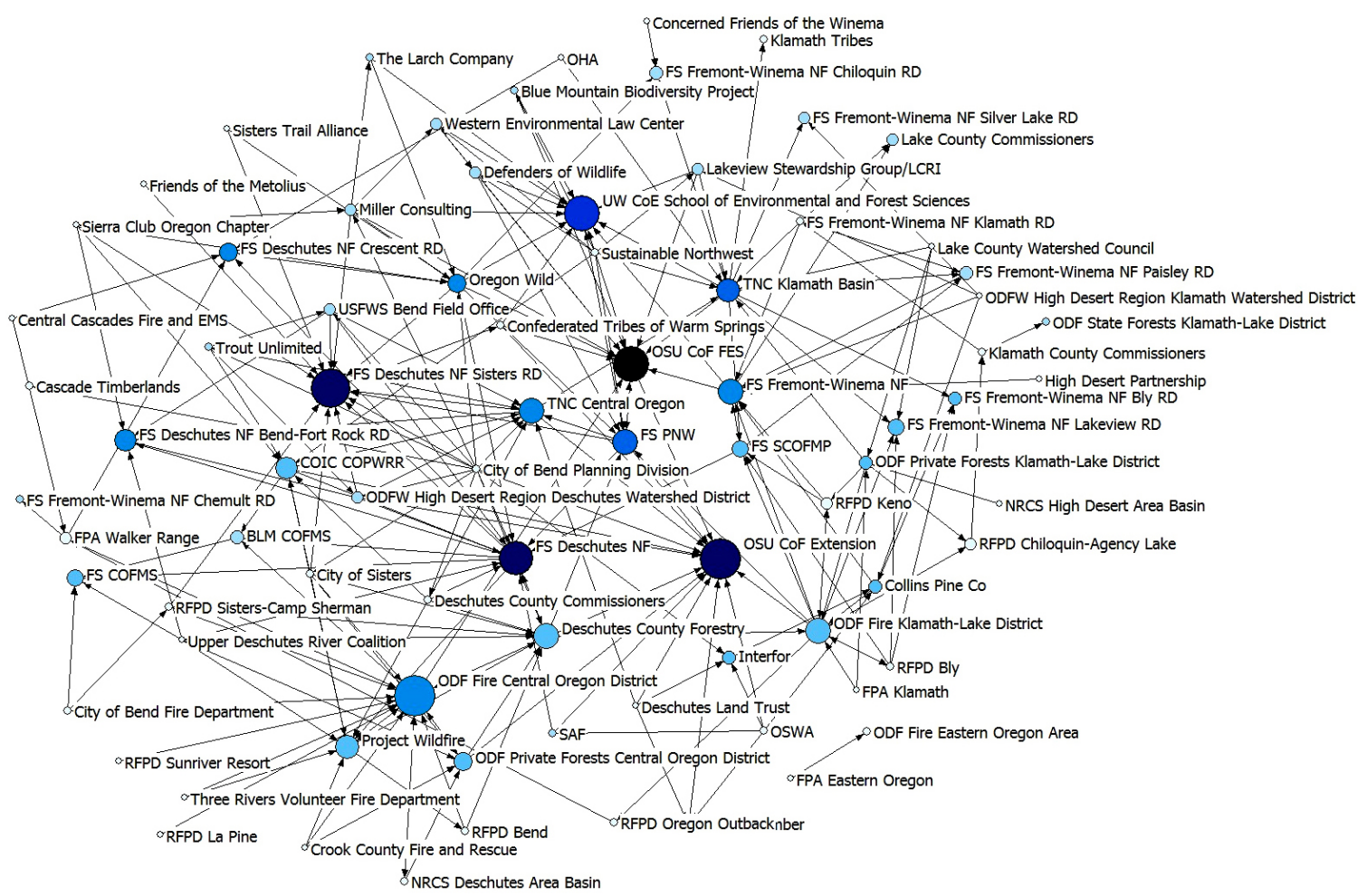


Table 4. Top 10 organizations ranked by total number of heterophilous ties to information sources.

\begin{tabular}{|c|c|c|c|c|c|c|c|}
\hline & \multirow[b]{2}{*}{$\begin{array}{c}\text { Indegree } \\
\text { Centrality }\end{array}$} & \multicolumn{6}{|c|}{ Heterophilous Ties } \\
\hline & & Geography & Goals & $\begin{array}{l}\text { Target } \\
\text { Lands }\end{array}$ & $\begin{array}{l}\text { Planning } \\
\text { Scale }\end{array}$ & $\begin{array}{c}\text { Fire } \\
\text { Attitude }\end{array}$ & Total \\
\hline OSU CoF FES & 12 & 9 & 1 & 9 & 6 & 9 & 34 \\
\hline OSU CoF Extension & 14 & 4 & 7 & 3 & 4 & 9 & 27 \\
\hline FS Deschutes NF & 11 & 2 & 6 & 6 & 5 & 6 & 25 \\
\hline FS Deschutes NF Sisters RD & 13 & 1 & 4 & 4 & 9 & 7 & 25 \\
\hline $\begin{array}{l}\text { UW CoE School of Environmental and Forest } \\
\text { Sciences }\end{array}$ & 12 & 7 & 0 & 2 & 6 & 5 & 20 \\
\hline FS PNW & 8 & 5 & 2 & 3 & 2 & 4 & 16 \\
\hline TNC Klamath Basin & 7 & 3 & 2 & 4 & 2 & 5 & 16 \\
\hline ODF Fire Central Oregon District & 14 & 1 & 2 & 0 & 2 & 10 & 15 \\
\hline FS Deschutes NF Crescent RD & 5 & 1 & 3 & 3 & 3 & 3 & 13 \\
\hline TNC Central Oregon & 8 & 1 & 2 & 4 & 2 & 4 & 13 \\
\hline FS Fremont-Winema NF & 8 & 0 & 5 & 4 & 2 & 2 & 13 \\
\hline
\end{tabular}

FS Deschutes NF, U.S. Forest Service Deschutes National Forest; FS Deschutes NF Crescent RD, U.S. Forest Service Deschutes National Forest Crescent Ranger District; FS Deschutes NF Sisters RD, U.S. Forest Service Deschutes National Forest Sisters Ranger District; FS Fremont-Winema NF, U.S. Forest Service Fremont-Winema National Forest; FS PNW, U.S. Forest Service Pacific Northwest Research Station; ODF Fire, Oregon Department of Forestry's Fire Protection Division; OSU CoF Extension, Oregon State University College of Forestry Extension; OSU CoF FES, Oregon State University College of Forestry Department of Forest Ecosystems and Society; TNC, The Nature Conservancy; UW CoE, University of Washington College of Environment.

Table 5. Top 10 organizations ranked by number of ties to working partners and information sources that focus on other geographic areas.

\begin{tabular}{lcc}
\hline \hline & \multicolumn{2}{c}{ Geography } \\
\cline { 2 - 3 } & Works & Info \\
& With & From \\
\hline Cascade Timberlands & 9 & 1 \\
Oregon Wild & 8 & 1 \\
OSU CoF FES & 7 & 9 \\
OSU CoF Extension & 6 & 4 \\
FS Fremont-Winema NF & 6 & 0 \\
Sustainable Northwest & 6 & 0 \\
UW CoE School of Environmental and & 5 & 7 \\
Forest Sciences & 5 & 2 \\
FS Deschutes NF & 5 & 1 \\
Walker Range FPA & 4 & 5 \\
FS PNW & \multicolumn{2}{c}{4} \\
FPA, Forest Protection Association; FS Deschutes NF, U.S. \\
Forest Service Deschutes National Forest; FS Fremont- \\
Winema NF, U.S. Forest Service Fremont-Winema National \\
Forest; FS PNW, U.S. Forest Service Pacific Northwest \\
Research Station; OSU CoF Extension, Oregon State \\
University College of Forestry Extension; OSU CoF FES, \\
Oregon State University College of Forestry Department of \\
Forest Ecosystems and Society; UW CoE, University of \\
Washington College of Environment. \\
\hline
\end{tabular}

All the same, increasing wildfire risk can be attributed to trends that are consistent across the ecoregion. Collective ecoregionwide problem solving and coordinated planning would likely be fruitful. The lack of interaction between ecosystem-north and ecosystem-south organizations suggests that organizations across the ecoregion, many of which seek to influence conditions on the same types of ownerships, e.g., national forest lands, are not coordinating planning or bringing their knowledge and resources to bear on a common problem to the extent possible.

Homophily structured the network above and beyond geography, however. Despite the potential complementarity of forest restoration and fire protection, organizations with these two different overarching goals did not appear to frequently work together or seek information from each other, i.e., more than expected by chance, and organizations with different attitudes toward wildfire did not work together frequently. This finding suggests that despite recent policy initiatives and a growing advocacy movement to integrate protection and restoration goals and strategies (DellaSala 2003, Butler and Goldstein 2010, Wildland Fire Leadership Council 2016), the institutional cultures of fire protection and forest restoration remain distinct, even in the ECE where significant progress has been made on collaboration on forest and, separately, fire management (Davis et al. 2012, Oregon Solutions 2013, Summers 2014). This cleavage between forest restoration and fire protection may be a legacy of the long history of state and federal policy that has separated fire protection and forest restoration administratively and prioritized the fire suppression in forested areas (Steelman and Burke 2007), a policy pattern that arguably has yielded insular institutional tendencies that are difficult to change (Sabatier et al. 1995, Fischer et al. 2016). A lack of communication and cooperation among forest restoration and fire protection organizations could hinder recognition of interdependencies between fire protection and 
forest restoration and joint efforts to solve the growing problem of wildfire risk. Similarly, a lack of working relationships among organizations with different attitudes toward fire could lead to the perpetuation of social conflict around management of fireprone forests and wildfire.

Our finding that organizations that focused on federal and nonfederal lands tended to work among themselves and not with each other also raises concerns. Lack of coordination between these types of organizations could hinder efforts to restore forests and prevent the potential spread of wildfire across ownership boundaries. In many areas of the ECE, federal lands are bordered and interspersed with nonfederal lands, particularly private forest and residential lands. Because wildfire burns irrespective of property boundaries, decisions to reduce flammable vegetation or not to do so can influence risk at large spatial scales. Owners who fail to reduce hazardous vegetation on their properties can enable the spread of wildfire to larger areas (Calkin et al. 2014). Coordinated efforts to reduce hazardous fuel along property lines and around structures and stands of trees can help minimize this risk. Unintended consequences of not coordinating management across ownership boundaries can be disastrous (Ryan et al. 2013). For example, a prescribed fire on lands managed for restoration can escape onto lands managed for fire protection, damaging timber or structures, or a naturally ignited fire on lands where hazardous fuel has accumulated because of fire suppression can burn at high severity, damaging lands managed for restoration. Of course, coordination by just a few organizations may lead to great impacts if the organizations influence large amounts of land or use particularly effective planning and management strategies. However, we found that even the small set of organizations that claimed to plan and manage forests and wildfire risk across ownership boundaries did not display a tendency for working with or seeking information and expertise from each other.

Coordination among different ownership groups has been hindered by social and policy barriers in the past (Knight and Landres 1998, Landres et al. 1998, Bergmann and Bliss 2004, Fischer and Charnley 2012). However, recently state and federal agencies have increased policy emphasis on all lands management and collaborative forest planning (USDA 2009, Tidwell 2010, Wildland Fire Leadership Council 2016). Moreover, federally and nonfederally focused organizations cooperate on other issues. For example, the FS and BLM are party to mutual aid agreements with the Oregon Department of Forestry's Fire Protection Division (ODF Fire) and local municipal fire departments and Rural Fire Protection Districts. This groundwork could arguably have led to more coordinated planning and management between organizations that focus on federal and nonfederal lands. Instead, one interpretation of our findings is that these agencies and interest groups may have coalesced into inward-focused policy subgroups that face difficulty considering other ownerships in the landscapes they dominate.

In spite of the lack of cohesion in the overall network, we found evidence of bonding social capital in the structure of some subnetworks of organizations, for example, the subnetworks of forest restoration and federal lands organizations that work together, and the subnetworks of fire protection and nonfederal lands organizations that seek information from each other. The relatively strong homophily and social cohesion in these subnetworks creates conditions for communication, mutual understanding, trust, and ultimately collective action. On the other hand, high bonding social capital can give rise to homogeneity, jeopardizing a network's ability to maintain a diverse knowledge and resource base (Reagans and Zuckerman 2001, Ruef 2002, Borgatti and Cross 2003, Reagans and McEvily 2003). It can also lead to the suppression of new ideas and exclusion of actors that try to voice new ideas. Forest restoration organizations, for example, may be well positioned to build common understanding of the wildfire problem and mutually acceptable strategies for addressing it. They may also have the social organization that would foster coordinated forest restoration practices. On the other hand, because they tend to source information mainly from themselves, they may lack exposure to new ideas and resources, for example, those of fireprotection organizations, that could help them optimize innovation. Moreover, as they become more cohesive, they may be less willing to entertain alternative ideas.

\section{Opportunities for increasing adaptive capacity}

Although it generally takes situations of stress or scarcity to compel different interests to work together (Benjamin et al. 2011, Wolf 2011), deliberate interventions in organizational networks can counter tendencies toward homophily, thereby enhancing social capacity to adapt to environmental change (Adger 2003, Valente 2012). The choice of such interventions depends on the root cause of the homophily. Although our findings suggested strong homophily in the network of organizations concerned with wildfire risk in the ECE, additional data would be needed to conclude whether the homophily we observed was a result of insularity and unwillingness on the part of the organizations to work across boundaries or external barriers that impede interaction. Assuming interaction is constrained by external barriers, organizations with extensive, diverse networks could be leveraged to foster learning and complex problem solving within the overall network. Network analysis can be used to identify these organizations.

Our analysis revealed that TNC Central Oregon, FS Deschutes $\mathrm{NF}$, and the conservation group Oregon Wild not only had extensive networks but were also engaged in particularly heterogeneous working relationships (Table 3, Fig. 3), which positions them well to facilitate interactions among diverse organizations. Similarly, OSU CoF FES, OSU CoF Extension, and FS Deschutes NF Sisters RD were well positioned to help disseminate information because they served as sources of information and expertise for particularly large and diverse sets of organizations (Table 4, Fig. 4). These organizations could be engaged in deliberate efforts to bridge social and geographic boundaries and build connectivity among stakeholders in the management of large fire-prone landscapes.

The greater indegree centrality of ecoregion-wide organizations as compared to ecoregion-north and ecoregion-south organizations suggests that ecoregion-wide organizations have opportunity to broker relations among subecoregional groups. Indeed, 4 of the 10 ecoregion-wide organizations were among the most heterophilous organizations in the network based on crossgeography ties (Table 5): the former Cascade Timberlands, a forestland management firm whose assets were recently sold to another forest resource company; OSU CoF FES; the nonprofit 
organization Sustainable Northwest; and FS Pacific Northwest Research Station (FS PNW). Also, the following were named as working partners by particularly diverse sets of organizations as defined by geographic focus (Table 5): the ecoregion-north office of Oregon Wild; OSU CoF Extension, which we considered an ecoregion-north organization because no extension foresters were based in the southern part of the ecoregion; University of Washington College of Environment School of Environmental and Forest Sciences (UW CoE School of Environmental and Forest Sciences), which we considered an ecoregion-south organization because of its focus on issues in Lake County; and FS Fremont-Winema NF, an ecoregion-south organization. FS Deschutes NF was party to almost $10 \%$ of all working relationships between organizations that focused on federal and nonfederal lands (Table 3). OSU CoF FES and FS PNW were identified as sources of information and expertise by a relatively wide range of organizations (Table 4, Fig. 4).

A number of organizations also appeared to bridge the divide between forest restoration and fire protection. Interfor, a forest product company, and FS Deschutes NF each accounted for 5\% of all forest restoration/fire protection goal ties in the "works with" network, and OSU CoF Extension accounted for 10\% of forest restoration/fire protection goal ties in the "info from" network. TNC Central Oregon and FS Deschutes NF were identified as working partners by more fire protection organizations than any other forest restoration organizations, and ODF Fire Central Oregon was identified as a working partner and information source by more forest restoration organizations than any other fire protection organization. Some of these same organizations were also well positioned to facilitate interaction between organizations that focused on federal and nonfederal lands. FS Deschutes NF was named as a working partner by more organizations focused on nonfederal lands than any other organization focused on federal lands, and OSU CoF FES was named as an information source by a relatively large number of organizations focused on nonfederal lands. These organizations are particularly well positioned to coordinate efforts to address increasing wildfire risk across ownership boundaries.

The relatively high indegree centrality of some organizations indicated that these organizations may be well positioned to increase the adaptive capacity of the network. Oregon Wild, for example, a forest restoration organization, was one of the most central organizations, in part because of the efforts of one key individual who led network-building efforts in the northern part of the ecoregion at the time of the study. Similarly, the FS national forest offices and ranger districts, which we classified as forest restoration organizations, have increasingly engaged in collaborative partnerships to increase public support and understanding of their management practices. TNC, another very central forest restoration organization, builds partnerships as one of its main strategies. The three most central organizations in the network, i.e., FS Deschutes NF, Oregon Wild, and TNC Central Oregon, were forest restoration organizations and also had particularly diverse networks of working partners (Table 3, Fig. 3). The large and diverse networks of these organizations could be leveraged to increase communication, coordination, and joint problem solving around the problem of increasing wildfire risk in the ECE.

\section{CONCLUSION}

Network analysis enabled us to characterize and explain the structural conditions that arguably could influence collective action and complex problem solving among diverse organizations. Despite the reputation of ERG models for being difficult to converge (Lusher et al. 2013), we fit models of tie formation among organizations concerned with increasing wildfire risk in the ECE. We found that although the network of organizations concerned with wildfire risk was not cohesive and thus not optimally positioned to foster collective action or complex problem solving to the extent possible, some organizations occupy positions in the network that could allow them to facilitate adaptive processes. Our research confirmed that homophily is a powerful influence on social organization even in cases where diverse organizations share concern about pressing natural resource problems. Although our findings suggested strong homophily in the network of organizations concerned with wildfire risk in the ECE, it is beyond our scope to infer that this homophily has hindered adaptation. Additional data would be needed to conclude whether the homophily we observed has impeded learning about how to develop and engage in anticipatory actions to prepare for future change or coordination of such actions so they occur on scales and with impacts sufficient to address change. Additional data about the root cause of homophily would also be needed to identify the appropriate policy intervention to reduce homophily if it were found to be a limiting factor. However, given that homophily can limit opportunity for learning by constraining the diversity of ideas to which one is exposed, our results validate and suggest continued need for network governance interventions to encourage organizations with diverse goals, attitudes, and geographic foci to interact. We used network analysis to identify organizations that could be leveraged to encourage such interaction, although we recognize that the choice of a specific intervention would depend on more information about the cause of homophily. We also recognize that even with such interventions, networks may resist becoming more heterophilous because of deep-seated power dynamics and legacies of policy mandates that have historically incentivized homophily (McPherson et al. 2001).

Our research provides an example of a method for assessing capacity to adapt to environmental change through quantification of the bonding and bridging social capital in a network. By identifying factors that can shape patterns of interaction among organizations, we provide insight on the utility of a structural approach for investigating human capacity for adaptation. This approach could be applicable in other regions of the United States and the world where people are recognizing the need to adapt to environmental changes that affect multiple ownership types and stakeholder groups in a common area.

Despite the existence of bridging organizations in the network we investigated, some research studies indicate that the rate of restoration actions across some landscapes may not be sufficient to strongly reduce the amount of high-severity fire (North et al. 2012, Barros et al. 2017, Spies et al. 2017). Part of this problem may result from conflicts with other management goals that limit the magnitude of treatments. For example, limits on smoke production from prescribed fire to protect human health may constrain the level of restoration and fire risk at landscape scales 
(Barros et al. 2017). Moreover, divisions between organizations with different attitudes toward fire, goals for landscape conditions, and territories and scales for management most certainly limit learning and collective action, and thus adaptation to increasing wildfire risk. We did not measure feedbacks between social networks and landscape outcomes, but they are an important and poorly understood component of socialecological adaptation (Berkes et al. 2003). A better understanding of how network structure influences how people and organizations frame natural resource problems such as wildfire risk and make decisions about how to address such problems through management may inform social-ecological adaptation frameworks.

An important next step for research on organizational networks and adaptation to environmental change is to better understand the relationship between network structures and adaptive behaviors. We suggest that developing statistical models to explain adaptive behavior as a function of network variables would be fruitful. Combining network analysis with data about human behavior may be a useful way to explore the influence of network structure on the policies and practices of organizations responding to environmental change.

Responses to this article can be read online at: http://www.ecologyandsociety.org/issues/responses. $\mathrm{php} / 8867$

\begin{abstract}
Acknowledgments:
The National Science Foundation's (NSF) Coupled Human and Natural Systems Program (NSF Grant CNH-1013296) and the U. $S$. Forest Service PNW Research Station provided the funding for this research. Support was also provided by the National SocioEnvironmental Synthesis Center (SESYNC; DBI-1052875). The authors would like to acknowledge all the interview informants who generously gave their time to participate in the study. The authors would also like to acknowledge Örjan Bodin for reviewing the study plan for the research; Susan Charnley, Emily Platt, and Kerry Grimm for assisting with data collection; Maribel Vidrio for assisting with data management; and Ken Vance-Borland for assisting with preliminary data analysis.
\end{abstract}

\section{LITERATURE CITED}

Adger, W. N. 2003. Social capital, collective action, and adaptation to climate change. Economic Geography 79 (4):387-404. http://dx.doi.org/10.1111/j.1944-8287.2003.tb00220. $\underline{\mathrm{X}}$

Agee, J. K. 1993. Fire ecology of Pacific Northwest forests. Island, Washington, D.C., USA.

Ager, A. A., N. M. Vaillant, M. A. Finney, and H. K. Preisler. 2012. Analyzing wildfire exposure and source-sink relationships on a fire prone forest landscape. Forest Ecology and Management 267:271-283. http://dx.doi.org/10.1016/j.foreco.2011.11.021
Andras, P., J. Lazarus, and G. Roberts. 2007. Environmental adversity and uncertainty favour cooperation. BMC Evolutionary Biology 7:240. http://dx.doi.org/10.1186/1471-2148-7-240

Andras, P., G. Roberts, and J. Lazarus. 2003. Environmental risk, cooperation, and communication complexity. Pages 49-65 in E. Alonso, D. Kudenko, and D. Kazakov, editors. Adaptive agents and multi-agent systems: adaptation and multi-agent learning. Springer-Verlag, New York, New York, USA. http://dx.doi. org/10.1007/3-540-44826-8 4

Angst, M., and C. Hirschi. 2016. Network dynamics in natural resource governance: a case study of Swiss landscape management. Policy Studies Journal. http://dx.doi.org/10.1111/ psj. 12145

Armitage, D. 2005. Adaptive capacity and community-based natural resource management. Environmental Management 35 (6):703-715. http://dx.doi.org/10.1007/s00267-004-0076-Z

Axelrod, R. 2000. On six advances in cooperation theory. Analyse \& Kritik: Journal of Social Philosophy and Social Theory 22:130-151. http://dx.doi.org/10.1515/auk-2000-0107

Axelrod, R., and W. D. Hamilton. 1981. The evolution of cooperation. Science 211(4489):1390-1396. http://dx.doi.org/10.1126/ science. 7466396

Barabási, A.-L., and R. Albert. 1999. Emergence of scaling in random networks. Science 286(5439):509-512. https://doi. org/10.1126/science.286.5439.509

Barros, A. M. G., A. A. Ager, M. A. Day, H. K. Preisler, T. A. Spies, E. White, R. Pabst, K. A. Olsen, E. Platt, J. D. Bailey, and J. P. Bolte. 2017. Spatiotemporal dynamics of simulated wildfire, forest management, and forest succession in central Oregon, USA. Ecology and Society 22(1):24. https://doi.org/10.5751/ ES-08917-220124

Benjamin, C. E., S. R. Brechin, and C. A. Thoms. 2011. Introduction to the special issue: organizational networks and environmental governance. Journal of Natural Resources Policy Research 3(3):211-222. http://dx.doi.org/10.1080/19390459.2011.591748

Berardo, R., and J. T. Scholz. 2010. Self-organizing policy networks: risk, partner selection, and cooperation in estuaries. American Journal of Political Science 54(3):632-649. http://dx.doi. org/10.1111/j.1540-5907.2010.00451.x

Bergmann, S. A., and J. C. Bliss. 2004. Foundations of crossboundary cooperation: resource management at the publicprivate interface. Society and Natural Resources 17(5):377-393. http://dx.doi.org/10.1080/08941920490430142

Berkes, F., J. Colding, and C. Folke, editors. 2003. Navigating social-ecological systems: building resilience for complexity and change. Cambridge University Press, Cambridge, UK.

Bodin, Ö., and B. I. Crona. 2009. The role of social networks in natural resource governance: what relational patterns make a difference? Global Environmental Change 19(3):366-374. http:// dx.doi.org/10.1016/j.gloenvcha.2009.05.002

Bodin, Ö., B. Crona, and H. Ernstson. 2006. Social networks in natural resource management: what is there to learn from a structural perspective? Ecology and Society 11(2):r2. http://dx. doi.org/10.5751/ES-01808-1102r02 
Bodin, Ö., and J. Norberg. 2005. Information network topologies for enhanced local adaptive management. Environmental Management 35(2):175-193. http://dx.doi.org/10.1007/s00267-004-0036-7

Borgatti, S. P., and R. Cross. 2003. A relational view of information seeking and learning in social networks. Management Science 49(4):432-445. http://dx.doi.org/10.1287/mnsc.49.4.432.14428

Borgatti, S. P., M. G. Everett, and L. C. Freeman. 2002. UCINET for Windows: software for social network analysis. Analytic Technologies, Harvard, Massachusetts, USA.

Borgatti, S. P., C. Jones, and M. G. Everett. 1998. Network measures of social capital. Connections 21(2):27-36.

Bowman, D. M. J. S., J. Balch, P. Artaxo, W. J. Bond, M. A. Cochrane, C. M. D'Antonio, R. DeFries, F. H. Johnston, J. E. Keeley, M. A. Krawchuk, C. A. Kull, M. Mack, M. A. Moritz, S. Pyne, C. I. Roos, A. C. Scott, N. S. Sodhi, and T. W. Swetnam. 2011. The human dimension of fire regimes on Earth. Journal of Biogeography 38(12):2223-2236. http://dx.doi.org/10.1111/ j.1365-2699.2011.02595.x

Burt, R. S. 2000. The network structure of social capital. Research in Organizational Behavior 22:345-423. http://dx.doi.org/10.1016/ $\underline{\text { s0191-3085(00)22009-1 }}$

Butler, W. H., and B. E. Goldstein. 2010. The US Fire Learning Network: springing a rigidity trap through multiscalar collaborative networks. Ecology and Society 15(3):21. http://dx. doi.org/10.5751/ES-03437-150321

Calkin, D. E., J. D. Cohen, M. A. Finney, and M. P. Thompson. 2014. How risk management can prevent future wildfire disasters in the wildland-urban interface. Proceedings of the National Academy of Sciences of the United States of America 111 (2):746-751. http://dx.doi.org/10.1073/pnas.1315088111

Carroll, M. S., P. J. Cohn, D. N. Seesholtz, and L. L. Higgins. 2005. Fire as a galvanizing and fragmenting influence on communities: the case of the RodeoÖChediski fire. Society and Natural Resources 18(4):301-320. http://dx.doi.org/10.1080/089$\underline{41920590915224}$

Carroll, M. S., T. Paveglio, P. J. Jakes, and L. L. Higgins. 2011. Nontribal community recovery from wildfire five years later: the case of the RodeoÖChediski fire. Society and Natural Resources 24(7):672-687. http://dx.doi.org/10.1080/08941921003681055

Cassidy, L., and G. D. Barnes. 2012. Understanding household connectivity and resilience in marginal rural communities through social network analysis in the village of Habu, Botswana. Ecology and Society 17(4):11. http://dx.doi.org/10.5751/ es-04963-170411

Charnley, S., T. A. Spies, A. M.G. Barros, E. M. White, and K. A. Olsen. 2017. Diversity in forest management to reduce wildfire losses: implications for resilience. Ecology and Society 22(1):22. https://doi.org/10.5751/ES-08753-220122

Cohen, M. D., R. L. Riolo, and R. Axelrod. 2001. The role of social structure in the maintenance of cooperative regimes. Rationality and Society 13(1):5-32. http://dx.doi. org/10.1177/104346301013001001

Coleman, J. S. 1990. Foundations of social theory. Harvard University Press, Cambridge, Massachusetts, USA.
Cuthbertson, B. H., and J. M. Nigg. 1987. Technological disaster and the nontherapeutic community: a question of true victimization. Environment and Behavior 19(4):462-483. http://dx. doi.org/10.1177/0013916587194004

Cutter, S. 2006. The geography of social vulnerability: race, class, and catastrophe. Understanding Katrina: perspectives from the social sciences. Social Science Resource Council, New York, New York, USA. [online] URL: http://understandingkatrina.ssrc.org/ $\underline{\text { Cutter/ }}$

Davis, E. J., C. Moseley, C. Evers, K. MacFarland, M. NeilsenPincus, A. Pomeroy, and M. J. Enzer. 2012. Community-based natural resource management in Oregon: a profile of organizational capacity. Ecosystem Workforce Program working paper no. 39, University of Oregon, Eugene, Oregon, USA.

DellaSala, D. A., A. Martin, R. Spivak, T. Schulke, B. Bird, M. Criley, C. van Daalen, J. Kreilick, R. Brown, and G. Aplet. 2003. A citizens' call for ecological forest restoration: forest restoration principles and criteria. Ecological Restoration 21(1):14-23. http:// dx.doi.org/10.3368/er.21.1.14

Desmarais, B. A., and S. J. Cranmer. 2012. Micro-level interpretation of exponential random graph models with application to estuary networks. Policy Studies Journal 40 (3):402-434. http://dx.doi.org/10.1111/j.1541-0072.2012.00459.x

Doreian, P., and K. L. Woodard. 1992. Fixed list versus snowball selection of social networks. Social Science Research 21:216-233. http://dx.doi.org/10.1016/0049-089X(92)90016-A

Drabeck, T. E. 1986. Human system responses to disaster: an inventory of sociological findings. Springer-Verlag, New York, New York, USA. http://dx.doi.org/10.1007/978-1-4612-4960-3

Dynes, R. R. 1970. Organized behavior in disaster. Lexington Books, Lexington, Massachusetts, USA.

Dynes, R. R., and E. L. Quarantelli. 1971. The absence of community conflict in the early phases of natural disaster. Pages 200-204 in C. G. Smith, editor. Conflict resolution: contributions of the behavioral sciences. University of Notre Dame Press, South Bend, Indiana, USA.

Fall, J. J. 2003. Planning protected areas across boundaries. Journal of Sustainable Forestry 17(1-2):81-102. http://dx.doi. org/10.1300/j091v17n01 06

Fischer, A. P. 2011. Reducing hazardous fuels on nonindustrial private forests: factors influencing landowner decisions. Journal of Forestry 109(5):260-266.

Fischer, A. P., and S. Charnley. 2012. Risk and cooperation: managing hazardous fuel in mixed ownership landscapes. Environmental Management 49(6):1192-1207. http://dx.doi. org/10.1007/s00267-012-9848-Z

Fischer, A. P., T. A. Spies, T. A. Steelman, C. Moseley, B. R. Johnson, J. D. Bailey, A. A. Ager, P. Bourgeron, S. Charnley, B. M. Collins, J. D. Kline, J. E. Leahy, J. S. Littell, J. D. A. Millington, M. Nielsen-Pincus, C. S. Olsen, T. B. Paveglio, C. I. Roos, M. M. Steen-Adams, F. R. Stevens, J. Vukomanovic, E. M. White, and D. M. J. S. Bowman. 2016. Wildfire risk as a socio-ecological pathology. Frontiers in Ecology and the Environment 14 (5):276-284. http://dx.doi.org/10.1002/fee.1283 
Flannigan, M., A. S. Cantin, W. J. de Groot, M. Wotton, A. Newbery, and L. M. Gowman. 2013. Global wildland fire season severity in the 21st century. Forest Ecology and Management 294:54-61. http://dx.doi.org/10.1016/j.foreco.2012.10.022

Folke, C., J. Colding, and F. Berkes. 2003. Synthesis: building resilience and adaptive capacity in social-ecological systems. Pages 352-387 in F. Berkes, J. Colding, and C. Folke, editors. Navigating social-ecological systems: building resilience for complexity and change. Cambridge University Press, Cambridge, UK.

Gargiulo, M., and M. Benassi. 2000. Trapped in your own net? Network cohesion, structural holes, and the adaptation of social capital. Organization Science 11(2):183-196. http://dx.doi. org/10.1287/orsc.11.2.183.12514

Gatewood, J. B. 1984. Cooperation, competition, and synergy: information-sharing groups among southeast Alaskan salmon seiners. American Ethnologist 11(2):350-370. http://dx.doi. org/10.1525/ae.1984.11.2.02a00080

Goodreau, S. M., M. S. Handcock, D. R. Hunter, C. T. Butts, and M. Morris. 2008. A statnet tutorial. Journal of Statistical Software 24(9):1-26.

Gordon, H. S. 1954. The economic theory of a common-property resource: the fishery. Journal of Political Economy 62:124-142. http://dx.doi.org/10.1086/257497

Granovetter, M. S. 1973. The strength of weak ties. American Journal of Sociology 78(6):1360-1380. http://dx.doi.org/10.1086/225469

Gupta, J., C. Termeer, J. Klostermann, S. Meijerink, M. van den Brink, P. Jong, S. Nooteboom, and E. Bergsma. 2010. The adaptive capacity wheel: a method to assess the inherent characteristics of institutions to enable the adaptive capacity of society. Environmental Science and Policy 13(6):459-471. http:// dx.doi.org/10.1016/j.envsci.2010.05.006

Henry, A. D. 2011. Ideology, power, and the structure of policy networks. Policy Studies Journal 39(3):361-383. http://dx.doi. org/10.1111/j.1541-0072.2011.00413.X

Henry, A. D., M. Lubell, and M. McCoy. 2011. Belief systems and social capital as drivers of policy network structure: the case of California regional planning. Journal of Public Administration Research and Theory 21(3):419-444. http://dx.doi.org/10.1093/ jopart/muq042

Hessburg, P. F., J. K. Agee, and J. F. Franklin. 2005. Dry forests and wildland fires of the inland northwest USA: contrasting the landscape ecology of the pre-settlement and modern eras. Forest Ecology and Management 211(1-2):117-139. http://dx.doi. org/10.1016/j.foreco.2005.02.016

Janssen, M. A., M. L. Schoon, W. Ke, and K. Börner. 2006. Scholarly networks on resilience, vulnerability and adaptation within the human dimensions of global environmental change. Global Environmental Change 16(3):240-252. http://dx.doi. org/10.1016/j.gloenvcha.2006.04.001

Jasny, L., and M. Lubell. 2015. Two-mode brokerage in policy networks. Social Networks 41:36-47. http://dx.doi.org/10.1016/j. socnet.2014.11.005
Knight, R. L., and P. B. Landres. 1998. Stewardship across boundaries. Island, Washington, D.C., USA.

Landres, P. B., R. L. Knight, S. T. A. Pickett, and M. L. Cadenasso. 1998. Ecological effects of administrative boundaries. Pages 39-64 in R. L. Knight and P. B. Landres, editors. Stewardship across boundaries. Island, Washington, D.C., USA.

Laumann, E. O., P. V. Marsden, and D. Prensky. 1983. The boundary specification problem in network analysis. Pages 18-34 in R. S. Burt and M. J. Minor, editors. Applied network analysis: a methodological introduction. Sage, Beverly Hills, California, USA.

Lemos, M. C., and A. Agrawal. 2006. Environmental governance. Annual Review of Environment and Resources 31:297-325. http:// dx.doi.org/10.1146/annurev.energy.31.042605.135621

Lin, N. 1999. Building a network theory of social capital. Connections 22(1):28-51.

Lubell, M., A. D. Henry, and M. McCoy. 2010. Collaborative institutions in an ecology of games. American Journal of Political Science 54(2):287-300. http://dx.doi.org/10.1111/j.1540-5907.2010.00431. $\underline{\mathrm{X}}$

Lubell, M., G. Robins, and P. Wang. 2014. Network structure and institutional complexity in an ecology of water management games. Ecology and Society 19(4):23. http://dx.doi.org/10.5751/ es-06880-190423

Lusher, D., J. Koskinen, and G. Robins, editors. 2013. Exponential random graph models for social networks. Cambridge University Press, New York, New York, USA. http://dx.doi.org/10.1017/ $\underline{\text { cbo9780511894701 }}$

Macy, M. W., J. A. Kitt, A. Flache, and S. Benard. 2003. Polarization in dynamic networks: a Hopfield model of emergent structure. Pages 162-173 in R. Breiger, K. Carley, P. Pattison, editors. Dynamic social network modeling and analysis. National Academies, Washington, D.C., USA.

Mandarano, L. A. 2009. Social network analysis of social capital in collaborative planning. Society and Natural Resources 22 (3):245-260. http://dx.doi.org/10.1080/08941920801922182

McPherson, M., L. Smith-Lovin, and J. M. Cook. 2001. Birds of a feather: homophily in social networks. Annual Review of Sociology 27:415-444. http://dx.doi.org/10.1146/annurev.soc.27.1.415

Merschel, A. G., T. A. Spies, and E. K. Heyerdahl. 2014. Mixedconifer forests of central Oregon: effects of logging and fire exclusion vary with environment. Ecological Applications 24 (7):1670-1688. http://dx.doi.org/10.1890/13-1585.1

Moritz, M. A., E. Batllori, R. A. Bradstock, A. M. Gill, J. Handmer, P. F. Hessburg, J. Leonard, S. McCaffrey, D. C. Odion, T. Schoennagel, and A. D. Syphard. 2014. Learning to coexist with wildfire. Nature 515(7525):58-66. http://dx.doi.org/10.1038/ nature13946

Muñoz-Erickson, T. A., B. B. Cutts, E. K. Larson, K. J. Darby, M. Neff, A. Wutich, and B. Bolin. 2010. Spanning boundaries in an Arizona watershed partnership: information networks as tools for entrenchment or ties for collaboration? Ecology and Society 15(3):22. http://dx.doi.org/10.5751/ES-03390-150322 
Nelson, D. R., W. N. Adger, and K. Brown. 2007. Adaptation to environmental change: contributions of a resilience framework. Annual Review of Environment and Resources 32:395-419. http:// dx.doi.org/10.1146/annurev.energy.32.051807.090348

Newig, J., D. Günther, and C. Pahl-Wostl. 2010. Synapses in the network: learning in governance networks in the context of environmental management. Ecology and Society 15(4):24. http:// dx.doi.org/10.5751/ES-03713-150424

Nonaka, I. 1994. A dynamic theory of organizational knowledge creation. Organization Science 5(1):14-37. https://doi.org/10.1287/ orsc.5.1.14

Norris, F. H., S. P. Stevens, B. Pfefferbaum, K. F. Wyche, and R. L. Pfefferbaum. 2008. Community resilience as a metaphor, theory, set of capacities, and strategy for disaster readiness. American Journal of Community Psychology 41(1-2):127-150. http://dx.doi.org/10.1007/s10464-007-9156-6

North, M., B. M. Collins, and S. Stephens. 2012. Using fire to increase the scale, benefits, and future maintenance of fuels treatments. Journal of Forestry 110(7):392-401. http://dx.doi. org/10.5849/jof.12-021

Olsen, C. S., J. D. Kline, A. A. Ager, K. A. Olsen, and K. C. Short. 2017. Examining the influence of biophysical conditions on wildland-urban interface homeowners' wildfire risk mitigation activities in fire-prone landscapes. Ecology and Society 22(1):21. https://doi.org/10.5751/ES-09054-220121

Omernik, J. M. 1987. Ecoregions of the conterminous United States. Annals of the Association of American Geographers 77 (1):118-125. http://dx.doi.org/10.1111/j.1467-8306.1987.tb00149. $\underline{x}$

Oregon Solutions. 2013. Oregon forest collaboratives: statewide inventory. Federal Forestlands Advisory Committee, Implementation Working Group, Portland, Oregon, USA.

Oregon State Legislature. 2013. Uncontrolled fire declared nuisance. Oregon revised statute 477.064. Oregon State Legislature, Salem, Oregon, USA.

Ostrom, E. 1990. Governing the commons: the evolution of institutions for collective action. Cambridge University Press, Cambridge, UK. http://dx.doi.org/10.1017/CBO9780511807763

Pahor, M., M. Škerlavaj, and V. Dimovski. 2008. Evidence for the network perspective on organizational learning. Journal of the American Society for Information Science and Technology 59 (12):1985-1994. http://dx.doi.org/10.1002/asi.20912

Peacock, W. G., and A. K. Ragsdale. 1997. Social systems, ecological networks and disasters. Pages 20-35 in W. G. Peacock, B. H. Morrow, and H. Gladwin. Hurricane Andrew: ethnicity, gender and the sociology of disasters. Routledge, London, UK.

Pelling, M., and C. High. 2005. Understanding adaptation: what can social capital offer assessments of adaptive capacity? Global Environmental Change 15(4):308-319. http://dx.doi.org/10.1016/ j.gloenvcha.2005.02.001

Powell, R. B. 2010. Developing institutions to overcome governance barriers to ecoregional conservation. Pages 53-66 in S. C. Trombulak and R. F. Baldwin, editors. Landscape-scale conservation planning. Springer, Dordrecht, the Netherlands. http://dx.doi.org/10.1007/978-90-481-9575-6_4

Ramirez-Sanchez, S., and E. Pinkerton. 2009. The impact of resource scarcity on bonding and bridging social capital: the case of fishers' information-sharing networks in Loreto, BSC, Mexico. Ecology and Society 14(1):22. http://dx.doi.org/10.5751/ ES-02841-140122

R Development Core Team. 2013. R: a language and environment for statistical computing. R Foundation for Statistical Computing, Vienna, Austria.

Reagans, R., and B. McEvily. 2003. Network structure and knowledge transfer: the effects of cohesion and range. Administrative Science Quarterly 48(2):240-267. http://dx.doi. org/10.2307/3556658

Reagans, R., and E. W. Zuckerman. 2001. Networks, diversity, and productivity: the social capital of corporate R\&D teams. Organization Science 12(4):502-517. http://dx.doi.org/10.1287/ orsc.12.4.502.10637

Reinhardt, E. D., R. E. Keane, D. E. Calkin, and J. D. Cohen. 2008. Objectives and considerations for wildland fuel treatment in forested ecosystems of the interior western United States. Forest Ecology and Management 256(12):1997-2006. http://dx.doi. org/10.1016/j.foreco.2008.09.016

Rogers, E. 1983. Diffusion of innovations. Free, New York, New York, USA.

Ruef, M. 2002. Strong ties, weak ties and islands: structural and cultural predictors of organizational innovation. Industrial and Corporate Change 11(3):427-449. http://dx.doi.org/10.1093/ icc/11.3.427

Ryan, K. C., E. E. Knapp, and J. M. Varner. 2013. Prescribed fire in North American forests and woodlands: history, current practice, and challenges. Frontiers in Ecology and the Environment 11(S1):e15-e24. http://dx.doi.org/10.1890/120329

Sabatier, P. A., J. Loomis, and C. McCarthy. 1995. Hierarchical controls, professional norms, local constituencies, and budget maximization: an analysis of US. Forest Service planning decisions. American Journal of Political Science 39(1):204-242. http://dx.doi.org/10.2307/2111764

Sandström, A., and L. Carlsson. 2008. The performance of policy networks: the relation between network structure and network performance. Policy Studies Journal 36(4):497-524. http://dx.doi. org/10.1111/j.1541-0072.2008.00281.x

Sandström, A., and C. Rova. 2010a. Adaptive co-management networks: a comparative analysis of two fishery conservation areas in Sweden. Ecology and Society 15(3):14. http://dx.doi. org/10.5751/ES-03531-150314

Sandström, A. C., and C. V. Rova. 2010b. The network structure of adaptive governance: a single case study of a fish management area. International Journal of the Commons 4(1):528-551. http:// dx.doi.org/10.18352/ijc.156

Škerlavaj, M., V. Dimovski, and K. C. Desouza. 2010a. Patterns and structures of intra-organizational learning networks within a knowledge-intensive organization. Journal of Information Technology 25:189-204. http://dx.doi.org/10.1057/jit.2010.3 
Škerlavaj, M., V. Dimovski, A. Mrvar, and M. Pahor. 2010b. Intraorganizational learning networks within knowledge-intensive learning environments. Interactive Learning Environments 18 (1):39-63. http://dx.doi.org/10.1080/10494820802190374

Smit, B., and J. Wandel. 2006. Adaptation, adaptive capacity and vulnerability. Global Environmental Change 16(3):282-292. http:// dx.doi.org/10.1016/j.gloenvcha.2006.03.008

Snijders, T. A. B., P. E. Pattison, G. L. Robins, and M. S. Handcock. 2006. New specifications for exponential random graph models. Sociological Methodology 36(1):99-153. https:// doi.org/10.1111/j.1467-9531.2006.00176.x

Society for Ecological Restoration (SER) International Science and Policy Working Group. 2004. The SER primer on ecological restoration, version 2 . SER International, Tucson, Arizona, USA.

Spies, T. A., E. White, A. Ager, J. D. Kline, J. P. Bolte, E. K. Platt, K. A. Olsen, R. J. Pabst, A. M.G. Barros, J. D. Bailey, S. Charnley, J. Koch, M. M. Steen-Adams, P. H. Singleton, J. Sulzman, C. Schwartz, and B. Csuti. 2017. Using an agent-based model to examine forest management outcomes in a fire-prone landscape in Oregon, USA. Ecology and Society 22(1):25. https://doi. org/10.5751/ES-08841-220125

Spies, T. A., E. M. White, J. D. Kline, A. P. Fischer, A. Ager, J. Bailey, J. Bolte, J. Koch, E. Platt, C. S. Olsen, D. Jacobs, B. Shindler, M. M. Steen-Adams, and R. Hammer. 2014. Examining fire-prone forest landscapes as coupled human and natural systems. Ecology and Society 19(3):9. http://dx.doi.org/10.5751/ es-06584-190309

Steelman, T. A., and C. A. Burke. 2007. Is wildfire policy in the United States sustainable? Journal of Forestry 105(2):67-72.

Summers, B. M. 2014. The effectiveness of forest collaborative groups at reducing the likelihood of project appeals and objections in eastern Oregon. Thesis, Environmental Science and Management Department, Portland State University, Portland, Oregon, USA.

Tidwell, T. 2010. An agenda for conservation in the 21st century. Speech to the National Association of State Foresters, Orlando, Florida, USA.

Tierney, K. J. 2007. From the margins to the mainstream? Disaster research at the crossroads. Annual Review of Sociology 33:503-525. http://dx.doi.org/10.1146/annurev.soc.33.040406.131743

U.S. Department of Agriculture (USDA). 2009. Agriculture Secretary Vilsack presents national vision for America's forests. USDA Office of Communications Release No. 0382.09. USDA, Washington, D.C. USA.

U.S. Forest Service. 2009. America's forests health update 2009. U.S. Forest Service, Forest Health Protection, Washington, D.C., USA.

Valente, T. W. 2012. Network interventions. Science 337:49-53. http://dx.doi.org/10.1126/science.1217330

Wasserman, S., and K. Faust. 1994. Social network analysis: methods and applications. Cambridge University Press, Cambridge, UK. http://dx.doi.org/10.1017/cbo9780511815478
Wildland Fire Leadership Council. 2016. Forests and rangelands. national cohesive wildland fire management strategy. Wildland Fire Leadership Council, Washington, D.C., USA. [online] URL: http://www.forestsandrangelands.gov/strategy/

Williams, J. 2013. Exploring the onset of high-impact mega-fires through a forest land management prism. Forest Ecology and Management 294:4-10. http://dx.doi.org/10.1016/j.foreco.2012.06.030

Wolf, S. A. 2011. Network governance as adaptive institutional response: the case of multifunctional forested landscapes. Journal of Natural Resources Policy Research 3(3):223-235. http://dx.doi. org/10.1080/19390459.2011.591760

Wolf, J., W. N. Adger, I. Lorenzoni, V. Abrahamson, and R. Raine. 2010. Social capital, individual responses to heat waves and climate change adaptation: an empirical study of two UK cities. Global Environmental Change 20(1):44-52. http://dx.doi. org/10.1016/j.gloenvcha.2009.09.004

Yoon, I. 2009. A mixed-method study of Princeville's rebuilding from the flood of 1999: lessons on the importance of invisible community assets. Social Work 54(1):19-28. http://dx.doi. org/10.1093/sw/54.1.19 